\title{
Directive Illocutionary Acts with Special Reference to Pitch Perfect
}

\author{
Putu Kurnia Utami \\ English Department, Faculty of Arts, Udayana University \\ [kurniautami18@gmail.com],
}

\begin{abstract}
Abstrak
Penelitian yang berjudul Directives Illocutionary Acts with Special Reference to Pitch Perfect bertujuan untuk menganalisa tipe dari mode ujaran dan arti dari tindak tutur tersebut dalam film Pitch Perfect. Dialog dalam film Pitch Perfect digunakan sebagai data. Pertama, film ditonton dan skrip film tersebut diunduh dari internet. Selagi membaca skrip, data yang potensial dicatat. Data kemudian diseleksi dan yang paling relevan kemudian dianalisis. Data dianalisis menggunakan dua teori, yaitu teori Speech Act yang dikemukakan oleh John $R$. Searle (1969) dan teori konteks situasi yang diperkenalkan oleh Halliday. Teori Speech Acts diaplikasikan untuk mengidentifikasi apakah sebuah ujuran termasuk kedalam tindak tutur direktif. Kemudian, teori konteks situasi digunakan untuk menganlisis arti implicit dari ujuran tersebut. Berdasarkan analisis yang telah dilakukan, tindak tutur direktif dapat diungkapkan melalui mode deklaratif, interogatif dan imperative dibawah dictum "I want you to do something". Ada 10 data dalam bentuk mode deklatarif, 10 data interogatif dan 5 data imperative. Arti implicit yang ditemukan dalam ujaran-ujaran tersebut adalah komando, mengundang, merequest, memberi masukan dan memohon.
\end{abstract}

Kata kunci: direktif, mode, konteks

\section{Abstract}

The current study entitled Directive Illocutionary Acts with Special Reference to Pitch Perfect aims to analyze the type of the modes of utterance and the forces of the illocutionary acts found in the Pitch Perfect movie. The current study used the dialogues taken from the Pitch Perfect movie as the data. First, the movie was watched and the script was downloaded. While reading the script, the potential data were noted. Furthermore, the data were selected and the relevant ones were analyzed. The data were analyzed using two main theories; the speech act theory by John R. Searle (1969) and the theory of context of situation proposed by Halliday (1989). The theory proposed by John R. Searle was used to identify whether or not the data were directives illocutionary acts. In addition, the theory proposed by Halliday was used to analyze the forces of the modes of utterances.Based on the analysis, it was found that directives illocutionary acts could be performed in three modes; declarative, interrogative and imperative under the dictum "I want you to do something". There were ten data in declarative mode, ten data in interrogative mode and 5 data in imperative mode had been analyzed. The forces of the modes of utterance found were commanding, inviting, requesting, advising and begging.

Key words: directive, moe, context

\section{Background}

Speech act is one of the sub divisions in pragmatics. It is an act that speaker performs when they are making an utterance. John R. Searle (1969:16) stated that "the reason for concentrating the study of speech acts is simply this: all linguistics communication involves linguistics acts. Austin (1955:94) proposed that there are three things we do when we use language in communication. He classifies the three 
types of speech acts, those are: the act of saying something (locutionary), what one does in saying it (illocutionary) and what one does by saying it (perlocutionary). According to Searle (1976, p.1 cited Senft 2014, p.31) "the basic unit of human linguistics communication is the illocutionary act" in the form of a 'complete sentence' produced under specific conditions. Illocutionary acts have an "effect" on the hearer, or it can be simply said that the hearer understands the speaker utterance.

In our daily lives, we consciously or unconsciously perform speech acts. The utterances that we produced often consist of indirect meaning. We found that, in many times, people not only performing utterances but also forcing the audience to do what they intended them to do. When the utterance of the speaker has a force and makes the hearer does what he or she says, the speaker performs an illocutionary act. The effect of the utterance on the hearer so he or she does whatever the speaker says, it can be said that the hearer performs a perlocutionary act.

It is often found that in our real life, most of act of requesting are actually realized as indirect speech acts. In actual conversation, explicit requests and imperatives are rarely used. Stephen Levinson (1983, p.264 cited Senft 2014, p. 38) points out that speakers of English 'could construct an indefinitely long list of ways of indirectly requesting an addressee' to do something like, e.g. passing the salt or closing the door.

Movie as one of the kinds of literary work reflects the reality. It gives such a representation of our real lives. The dialogues found in the movie were used as the data to analyze the directives illocutionary acts. It is really interesting to study how speakers use their language in a specific context.

\section{Problems}

a) What are the modes of utterances and their possible meanings under imperative dictum found in the Pitch Perfect movie?

b) What directive illocutionary forces are implied in the utterances found in the Pitch Perfect movie?

\section{Aims}

a) To identify and analyze the modes of utterances and their possible meanings under imperative dictum found in the Pitch Perfect movie.

b) To analyze the directive illocutionary forces of the modes of the utterances found in the Pitch Perfect movie.

\section{Research Method}

To conduct a scientific writing, it is necessary to follow a systematic way and scientific procedures to achieve a valid result. The research method used in this study can be divided into three parts; they are (1) data source, (2) method and technique of collecting data, (3) method of technique of analyzing data and (4) method and technique of presenting analysis which is explained further in the following sections.

\subsection{Data source}

As mentioned above, the data of the study were taken from one of the most popular movies entitled Pitch Perfect. It is an American comedy movie released in 2012 and directed by Jason Moore. It is the first film of the series, followed by the sequel, Pitch Perfect 2 (2015). Some very talented singers and actors are involved; they are Anna Kendrick, Skylar Astin, Rebel Wilson, Anna Camp, Brittany Snow, Ester Dean, Alexis Knapp, Hana Mae Lee, Adam Devine, Ben Platt, John Michael Higgins, and Elizabeth Banks.

The movie tells a story about the conflict and life of a girl a cappella group 
of Barden University, The Barden Bellas. They have a competitor from the same university, a boy a cappella group, The Trebbles. Both of the team join National Competition and eager to win. The movie is adapted from Mickey Rapkin's nonfiction book, entitled Pitch Perfect: The Quest for Collegiate a Cappella Glory. It is claimed that the movie become the second highest-grossing music comedy film of all time behind School of Rock.

\subsection{Method and technique of collecting data}

The data were collected using documentation method. There were some steps of data collection. First the movie was watched. Second, the script of the movies was downloaded from the internet. Furthermore, the script was read. While reading the script, the illocutionary acts found were noted and highlighted. Furthermore, if there are a lot of potential data found to be used, the data were selected into particular ones relevant to support the analysis. When the data were collected, they were classified based on the types of modes of the utterances, whether or not they were directives illocutionary acts and then the forces were analyzed.

\subsection{Method and technique of analyzing data}

The data in the current study were analyzed qualitatively. The data collected then were selected and the most potential and related one were descriptively analyzed based on the theory of this study. The first step to be done was distinguishing the data based on the types of the modes whether they were declarative, interrogative or imperative. The data were analyzed to get the possible utterance meanings of dictum based on the verbs indicating members of the directive illocutionary acts, they are asking, requesting, ordering, commanding, begging, pleading, praying, defying, permitting, advising, and inviting. To classify the data based on the type of illocutionary acts and find one which was directive illocutionary act, the speech act theory proposed by John R. Searle (1969) was used.

One utterance may have more than one meaning, and those will be considered as the ambiguity of the data. The theory of context of situation proposed by Halliday (1989) was applied to identify the illocutionary force of the collected data to avoid the ambiguous of the data since the three features (field, tenor and mode) will support the speaker's intention in performing the utterance and the emergence of the directives illocutionary acts.

\subsection{Method and technique of presenting analysis}

In presenting the result of data analysis, informal method is applied. By applying informal method, the data is explained descriptively in order to give a clear explanation which can be easily understood.

The procedures of the presentation of the result of data analysis are as follows:

a) The modes, dictum, forces and the types of illocutionary acts are put in the table.

b) Furthermore, it is explained further descriptively.

c) The analysis and the interpretation of the illocutionary forces are explained further descriptively by applying the theory of context of situation proposed by Halliday (1989).

\section{Result and discussion}

\subsection{The analysis of the three modes of} utterance

\subsection{1 "Hey Jesse, I am starving"}

This utterance might be simply understood as a statement. The $\mathrm{S}$ gives information to $\mathrm{H}$ that he/she is starving at the moment. The $\mathrm{H}$ is only receives 
information that the $\mathrm{S}$ is starving, the $\mathrm{H}$ is not asked to do some further action.

However, it can be also seen that there is something more than just a statement. The utterance can be also understood as a request or order. The $\mathrm{S}$ gives information to the $\mathrm{H}$ that he/she is starving and at the same time the $\mathrm{S}$ implicitly requests the $\mathrm{H}$ to provide $\mathrm{him} /$ her something to eat. The $\mathrm{H}$ is asked to do something for the $\mathrm{S}$.

Three utterance meanings; stating, ordering and requesting are found in "Hey Jesse, I am starving" and these makes the sentences ambiguous. There is only one illocutionary force in the utterance based on the context. To find the exact illocutionary force, the theory of context of situation proposed by Halliday is used.

\subsection{2 "Gonna audition this year?"}

There are some possible meanings of the utterance "Gonna audition this year?" such as asking, commanding, requesting, suggesting or inviting. This utterance can be interpreted as a question if the $\mathrm{S}$ does if only to get information from the $\mathrm{H}$ whether or not the $\mathrm{H}$ joins the audition. Therefore, the $\mathrm{H}$ can simply answer the S's question by saying yes or no without doing any further action. A command can be performed when the $\mathrm{S}$ and the $\mathrm{H}$ are not in the same status or social rank. The utterance can also be understood as a command if the $\mathrm{S}$ the honorable member of the group and the $\mathrm{H}$ is just the ordinary member. The $\mathrm{S}$ commands the $\mathrm{H}$ to join the audition this year. The $S$ uses his authority or privilege as the honorable member to tell somebody to do something. Therefore, this utterance can be considered as a command because the $\mathrm{H}$ has to obey what the $\mathrm{S}$ asks him to do.

The utterance can be also seen as a request where the $S$ is the ordinary member of the group and the $\mathrm{H}$ is the one who makes the decision. The $S$ request to the $\mathrm{H}$ whether or not the group join the audition this year. The $\mathrm{H}$ does not have to do what the $\mathrm{S}$ asks him to do because the $\mathrm{H}$ is in the higher position or status. For instance, the $\mathrm{H}$ is the boss and the $\mathrm{S}$ is the staff, the $\mathrm{S}$ asked the $\mathrm{H}$ whether or not he could leave early. Whatever the decision made by the $\mathrm{H}$, the $\mathrm{S}$ must obey it.

Inviting is usually performed by someone who host or manage an event to someone who he wants him to come or join. The utterance can also be understood as an invitation if the $\mathrm{S}$ is the committee of the audition and the $\mathrm{H}$ is the member of the group who usually joins the audition. The $\mathrm{S}$ invites the $\mathrm{H}$ to join the audition this year. The $\mathrm{H}$ does not have to accept it, he might reject it as it is just an invitation.

The utterance "Gonna audition this year?" can be considered as a suggestion if the $\mathrm{S}$ is someone who has a close relationship to the $\mathrm{H}$. For instance, the $\mathrm{S}$ is the H's best friend. The $\mathrm{S}$ knows that the $\mathrm{H}$ is potential to pass the audition. The $\mathrm{S}$ suggests the $\mathrm{H}$ to join the audition. Thus, the meaning of the utterance is suggesting. Five utterance meanings such as asking, commanding, requesting, inviting and suggesting are found in "Gonna audition this year?" and these five meanings make the utterance becomes ambiguous. Thus, the theory of context of situation is used to find the exact illocutionary force of the utterance.

\subsection{3 "Just get out of my face!"}

The utterance "Just get out of my face!" can be seen as an instruction or a command. The $\mathrm{H}$ is commanded to go away from the $\mathrm{S}$. The $\mathrm{H}$ is expected to do what the $S$ told him/her to do.

\subsection{The analysis of illocutionary forces 5.2.1 "Hey, Jesse, I am starving."$$
\mathrm{H} \quad \text { : "This is getting exhausted." }
$$$$
\text { S : "Hey, Jesse, I am starving." }
$$$$
\mathrm{H} \text { : "You want to get you lunch. }
$$ You should lay off the burgers}


though. You won't be twenty-two forever."

Field

The conversation occurred in the campus radio station in the afternoon. The H, Jesse, and his friend Beca are stacking cd's. They are working in there. The S, Luke, who is in charge of the radio station, is in the booth.

Tenor

There are two participants involved in the conversation; Jesse as the $\mathrm{H}$ and Luke as the $\mathrm{S}$. The $\mathrm{S}$ is a full-time-worker in the campus radio station. He is in charge of the music being played in the radio. The $\mathrm{H}$ is a part-time-worker in the campus radio station. He is responsible to stack the cd in the proper place.

Mode

The indirect illocution in declarative form performed by the $S$ is categorized as directive illocutionary act. The $\mathrm{H}$ is expected to do something in response to the $S$ ' utterance. It might be understood that the $\mathrm{H}$ utterance is a statement. However, the $\mathrm{S}$ does not merely inform that he is starving but also he expects the $\mathrm{S}$ to do something in response to his utterance. He indirectly requests the $\mathrm{H}$ to buy him lunch.

\subsection{2 "Gonna audition this year?"}

$\mathrm{S} \quad$ : "Hey, Barb! Gonna audition this year? We have openings.

$\mathrm{H} \quad$ : "Oh, now that you've puked your way to the bottom, you might actually consider me? I've auditioned three times and never got in because you said my boobs look like baloney."

Field

The conversation occurred on the first day of college. All of the club open booths to recruit new member. The $\mathrm{S}$ tries to convince the $\mathrm{H}$ to make her interested to join the club.

Tenor
There are two participants engaged in the conversation above; Chloe as the $\mathrm{S}$ and Barb as the $\mathrm{H}$. The $\mathrm{S}$ is the member of the girl A cappella group, Barden Bella. Both the $S$ and the $S$ are in the same year. The $\mathrm{H}$ has three times got rejected in the audition. Knowing the fact of what happened to the group in the last year competition, the $\mathrm{H}$ mocks the group. Mode

The interrogative mode of the utterance "Gonna audition this year?" is classified as indirect directive illocutionary act. The $\mathrm{S}$ does not intend to get information whether the $\mathrm{H}$ will join this year audition. However, she actually indirectly invites the $\mathrm{H}$ to join the audition.

\subsection{3 "Just get out of my face!"}

H : "Aubrey, calm down. She's not. I swear."

S : "God, Jesse! You are always trying to help me! I don't need helping! Just get out of my face!"

Field

The conversation occurred at the backstage hallway after the Bellas performance. The trebles sit around, going off, as the next group. An obviously upset Aubrey fiings the backstage door open. The rest of the Bellas amble in behind her. Aubrey is mad at the $S$ because she did something out of the scenario. She also accused the $S$ that she hangs out with the Trebles member, the $\mathrm{H}$. The $\mathrm{S}$ was sick of the $\mathrm{H}$ because he tries to help but he just makes everything worse.

Tenor

Beca as the $\mathrm{S}$ and Jesse as the $\mathrm{H}$ are both member of A cappella group from the same college. However; their group are rivals. There is a rule that none of the member form both group are allowed to date each other.

Mode 
The utterance above is categorized as direct directive illocutionary act in form of imperative mode. The $S$ directly wants the $\mathrm{H}$ to do something for her. She yelled at the $\mathrm{H}$ to get out of her face.

\section{Conclusion}

There are some points which can be drawn as the conclusion of the study based on the data analyzed about the directives illocutionary acts found Pitch Perfect movie.

Directive illocutionary acts can be performed in three modes; they are declarative, interrogative and imperative under the dictum "I want you to do something". There were ten data in form of declarative modes, ten data in form of interrogative modes and five data in form of imperative modes had been analyzed. It is found that most of the directives are performed indirectly in form of declarative and interrogative modes. The speaker implicitly asks the hearer to do something in response to his/her utterance. To perform a direct directive illocutionary act, the speaker uses the imperative modes. It is clear that the speaker intends the hearer to do something for him/her. The types of directive illocutionary acts found in the data analyzed are commanding, inviting, requesting, advising and begging.By analyzing the context (the field, tenor, and mode), it is easier to find the exact intention of the speaker so that ambiguity could be avoided.

\section{References}

Austin, J.L. (1962). How to Do Things with Words. New York. Oxford University Press

Halliday, M.A.K. (1989). Language, Context, and Text: Aspect of Language in a Social-Semiotic Perspective. Victoria: Deakin University
Levinson, C. Stephen. (1987). Pragmatics. Cambridge: Cambridge University Press

Searle, John R. (1969). Speech Act: An Essay in the Philosophy of Language. Cambridge: Cambridge University Press

Searle, John R. (1976). Language in Society, vol.5. Cambridge: Cambridge University Press

Searle, John R. (1981). Expression and Meaning: Studies in Theory of Speech Acts. Cambridge: Cambridge University Press

Searle, John R. (1998). Mind, Language and Society.Cambrdige: Cambridge University Press

Senft, Gunter. (2014). Understanding Pragmatics. New York: Routledg. 